Robert Suwaj

\title{
WIEK UCZESTNIKÓW POSTĘPOWANIA ADMINISTRACYJNEGO A SKUTECZNOŚĆ PODEJMOWANYCH PRZEZ NICH CZYNNOŚCI PRAWNYCH
}

\section{Wprowadzenie}

Z punktu widzenia logiki trudno jest zaakceptować skrót myślowy w postaci pojęcia „wiek uczestnika postępowania”, zaś jeszcze trudniej mówić - choć jest to stwierdzenie używane w judykaturze - o ,wieku strony postępowania”. Wiek nieodparcie kojarzy się z osobą fizyczną, której to pojęcie jest w powszechnym znaczeniu przypisane ${ }^{1}$. $Z$ uwagi zaś na wszechstronne formy aktywności osób fizycznych, które mogą przejawiać się właśnie w uzyskaniu statusu procesowego strony, biegłego czy świadka, postanowiłem przyjąć - na potrzeby niniejszego opracowania - poprawność użycia pojęcia „wiek uczestnika postępowania administracyjnego”, jako swoistego, aczkolwiek przyjętego i stosowanego w praktyce, skrótu myślowego. Pod pojęciem tym rozumiem - podobnie jak to rozumieć nakazuje słownik języka polskiego - stan biologicznej dojrzałości w różnych fazach rozwoju człowieka², ujmowany najczęściej w formie periodyzacji ${ }^{3}$.

Wiek osoby fizycznej jest w ustawodawstwie zagadnieniem ważnym, w zależności bowiem od osiagnięcia odpowiedniego jego stanu zaawansowania uzależniono możliwość korzystania z różnego rodzaju uprawnień (praw i wolności), ale też co często ma znaczenie bardziej istotne dla zainteresowanego - także konieczność

\footnotetext{
$1 \quad$ Jeszcze dalej idące skojarzenie wieku, tutaj w związku z pojazdem mechanicznym znajdujemy np. w art. 10 ust. 1 i 2 ustawy z dnia 12.01.1991 roku o podatkach i opłatach lokalnych, tekst jedn. Dz.U. z 2006 nr 121, poz. 844 ze zm., zgodnie z którym, przy określaniu stawek tam wskazanych, rada gminy uwzględnia m.in. rodzaj środka transportowego i jego wpływ na środowisko naturalne, dopuszczalną masę całkowita, rok produkcji albo wiek pojazdu, nacisk na siodło ciagnika albo liczbę miejsc do siedzenia.

2 http://encyklopedia.pwn.pl/haslo.php?id=3995582

3 Najczęściej jako: a) okres prenatalny (od poczęcia do narodzin), b) okres wczesnego dzieciństwa (od narodzin do 3 roku życia), c) wiek przedszkolny (od 4 do 6 roku życia), d) wiek szkolny (od 7 do 10-12 roku życia), e) okres adolescencji (od 10-12 do 20-23 roku życia), f) okres wczesnej dorosłości (od 20-23 do 35-40 roku życia), g) okres średniej dorosłości (od 35-40 do 55-60 roku życia) oraz h) okres późnej dorosłości (od 55-60 roku życia wzwyż).
} 
ponoszenia odpowiedzialności prawnej za swoje działania (bądź zaniechania). Na gruncie materialnego prawa administracyjnego od osiagnięcia wieku osoby fizycznej (w przedziale od 16 do 21 lat) uzależnia się możliwość np. otrzymania uprawnień do kierowania pojazdami mechanicznymi ${ }^{4}$, ale też wprowadza liczne obowiązki - w związku z osiagnnięciem określonego wieku (od 50 do 75 lat), dotyczące np. konieczności poddania się badaniom lekarskim ${ }^{5}$ lub ograniczenia, takie jak np.: możliwość prowadzenie pojazdu wyłącznie w dzień, ograniczenie prędkości jazdy, prowadzenie pojazdu wyłącznie w określonym obszarze, np. w promieniu $30 \mathrm{mil}$ od miejsca zamieszkania czy zakaz jazdy po autostradach ${ }^{6}$.

Rozwiązania ustrojowe także przewidują szereg ograniczeń wiekowych, szczególnie przy wykonywaniu określonych czynności zawodowych. I tak np. do pełnienia urzędu na stanowisku sędziego wojewódzkiego sądu administracyjnego może być powołany ten, kto - między innymi - ukończył 35 lat życia ${ }^{7}$. Z drugiej strony, przyjmuje się też maksymalny wiek do pełnienia określonych zawodów, np. kierownikiem apteki może być farmaceuta, który - obok spełnienia innych obowiązków określonych w art. 88 ustawy prawo farmaceutyczne ${ }^{8}-$ nie przekroczył 65 roku życia. Rozwiązanie powyższe wydaje się spełniać wymogi określone w art. 6 Dyrektywy Rady UE 2000/78/WE z dnia 27 listopada 2000 roku, ustanawiającej ogólne warunki ramowe równego traktowania w zakresie zatrudnienia i pracy. Na gruncie powyższej regulacji przyjęto, że odmienne traktowanie ze względu na wiek nie stanowi dyskryminacji, jeżeli w ramach prawa krajowego zostanie to obiektywnie i racjonalnie uzasadnione zgodnym z przepisami celem, w szczególności celami polityki zatrudnienia, rynku pracy i kształcenia zawodowego, i jeżeli środki mające służyć realizacji tego celu są właściwe i konieczne. Takie odmienne traktowanie może polegać np. na określeniu warunków dolnej granicy wieku, doświadczenia zawodowego lub stażu pracy, albo ustalenia górnej granicy wieku przy rekrutacji,

Zgodnie z art. 90 ustawy z dnia 20 czerwca 1997 r. Prawo o ruchu drogowym (Dz.U. Nr 98, poz. 602), prawo jazdy otrzymuje osoba, jeżeli: 1) osiagnęła wymagany dla danej kategorii wiek, 2) uzyskała orzeczenie lekarskie o braku przeciwwskazań zdrowotnych do kierowania pojazdem, 3) odbyła wymagane szkolenie, 4) zdała z wynikiem pozytywnym egzamin państwowy. 2. Wymagany dla danej kategorii wiek wynosi: 1) 16 lat - dla kategorii A1, B1 lub T, 2) 17 lat - dla kategorii A lub B, 3) 18 lat - dla kategorii B+E, C, C+E, C1 lub C1+E, 4) 21 lat dla kategorii D, D+E, D1 lub D1+E, z zastrzeżeniem ust. 4. 3. Osoba, która nie ukończyła 18 lat, może uzyskać prawo jazdy kategorii A, A1, B, B1 lub T za zgodą rodziców lub opiekuna. 4. Wymagany wiek do uzyskania prawa jazdy kategorii D lub D1 przez żołnierza zasadniczej służby wojskowej posiadającego prawo jazdy kategorii B wynosi 19 lat.

$5 \quad$ Np. w Niemczech, dwie grupy zawodowe - kierowcy autobusów po ukończeniu 50 roku życia i kierowcy taksówek po ukończeniu 60. roku życia muszą co 5 lat poddać się ogólnemu badaniu zdrowia, wzroku i szybkości reakcji, koncentracji, dopuszczalnego obciążenia organizmu itp. i spełnić przy tym dość wysokie wymogi, jeśli chca dalej wykonywać swój zawód - por. A. Dragan, Rozwiązania prawne dotyczące starszych kierowców w Stanach Zjednoczonych (USA), Niemczech i Austrii, opracowanie Działu Analiz i Opracowań Tematycznych Kancelarii Senatu RP, s. 4.

$6 \quad$ Ibidem, s. 3.

7 Art. $6 \S 1$ pkt 5 ustawy z dnia 25 lipca 2002 r. Prawo o ustroju sądów administracyjnych (Dz.U. Nr 153, poz. 1269 z późn. zm.).

8 Ustawa z dnia 6 września 2001 r. Prawo farmaceutyczne (tekst jedn. Dz.U. z 2008 r. Nr 45, poz. 271 z późn. $\mathrm{zm}$.). 
z uwzględnieniem wykształcenia wymaganego na danym stanowisku lub potrzeby racjonalnego okresu zatrudnienia przed przejściem na emeryturę.

Przedmiot niniejszego opracowania stanowić będą rozważania wiążące się regulacjami prawnymi dotyczącymi ograniczeń możliwości podejmowania czynności procesowych przez osoby fizyczne, będące uczestnikami ogólnego postępowania administracyjnego, które związane są z ich wiekiem.

Postanowiłem wyróżnić cztery kategorie takich uczestników. Najczęściej występującą formą uczestnictwa osób fizycznych jest oczywiście ich udział w charakterze strony postępowania, będącej podmiotem koniecznym każdej sprawy administracyjnej. Strona, o ile może występować w sprawie samodzielnie, posiada uprawnienie do ustanowienia pełnomocnika w postępowaniu administracyjnym, którym może być jednak wyłącznie osoba fizyczna mająca zdolność do czynności prawnych. W postępowaniu wymagającym przeprowadzenia czynności dowodowych możemy mieć do czynienia z udziałem świadków bądź biegłych, których skuteczność działań łączy się - w pewien sposób - z koniecznością osiąnnięcia określonego wieku.

\section{Znaczenie wieku strony postępowania dla jej zdolności procesowej}

Z punktu widzenia formalnego stroną abstrakcyjnego postępowania administracyjnego mogą być - obok osób prawnych, państwowych i samorządowych jednostek organizacyjnych i organizacji społecznych - także osoby fizyczne (art. 29 kpa.). Nie każda jednak osoba fizyczna, która może występować w postępowaniu administracyjnym jako strona, ma możliwość samodzielnego podejmowania prawnie wiążących czynności procesowych. Nie każda osoba fizyczna posiada więc tzw. zdolność procesową, pomimo posiadania interesu prawnego lub obowiązku w konkretnej sprawie administracyjnej.

Zdolność procesowa strony postępowania administracyjnego uzależniona jest od zdolności do czynności prawnych, której przesłanki są oceniane według przepisów ustawy z dnia 23 kwietnia 1964 r. Kodeks cywilny (Dz.U. Nr 16, poz. 93 ze zm.) - zwanym dalej „kc.”. W tym zakresie art. 30 § 1 k.p.a. odsyła wprost do przepisów kc. Stosownie zaś do postanowień kc. osoba fizyczna może mieć zdolność do czynności prawnych pełną, ograniczoną lub nie posiadać jej w ogóle.

Pełną zdolność do czynności prawnych posiadają osoby pełnoletnie, tj. te, które ukończyły osiemnasty rok życia i nie są ubezwłasnowolnione. Dodatkowo jednak małoletni uzyskuje pełnoletność przez zawarcie małżeństwa, przy czym nie traci jej w razie unieważnienia małżeństwa. Istotą pełnej zdolności do czynności prawnych 
jest możliwość dokonywania wszelkich dopuszczanych przez prawo czynności zmierzających do nabycia lub rozporządzenia prawem oraz zaciagnięcia zobowiązania. W postępowaniu administracyjnym pełna zdolność do czynności prawnych pozwala osobie fizycznej, która nie jest ubezwłasnowolniona, na skuteczne podejmowanie czynności procesowych osobiście lub też na samodzielne ustanowienie w sprawie pełnomocnika. Kryterium wieku w postaci ukończenia przez osobę fizyczną 18 lat będzie więc stanowiło zasadniczą przesłankę uznania jej za upoważnioną do osobistego działania w sprawie administracyjnej.

Nie mają natomiast zdolności do czynności prawnych osoby, które nie ukończyły lat trzynastu oraz osoby ubezwłasnowolnione całkowicie. Osoba, która ukończyła lat trzynaście, może być ubezwłasnowolniona całkowicie, jeżeli wskutek choroby psychicznej, niedorozwoju umysłowego albo innego rodzaju zaburzeń psychicznych, w szczególności pijaństwa lub narkomanii, nie jest w stanie kierować swym postępowaniem. Dla ubezwłasnowolnionego całkowicie ustanawia się opiekę, chyba że pozostaje on jeszcze pod władzą rodzicielską. Na gruncie prawa cywilnego przyjmuje się, że czynność prawna dokonana przez osobę, która nie ma zdolności do czynności prawnych, jest nieważna, tzn. nie wywołuje żadnych skutków prawnych. $\mathrm{W}$ ogólnym postępowaniu administracyjnym przewidziano, że zgodnie z art. $30 \S$ 2 k.p.a. „osoby fizyczne nie posiadające zdolności do czynności prawnych działają przez swych ustawowych przedstawicieli”. W konsekwencji powyższego przyjmuje się, że czynność prawna dokonana przez osobę, która nie ma zdolności do czynności prawnych, jest nieważna (art. $14 \S 1 \mathrm{kc}$.). Nieukończenie lat trzynastu będzie więc powodowało brak prawnych możliwości skutecznego działania w postępowaniu administracyjnym.

Ograniczoną zdolność do czynności prawnych mają małoletni, którzy ukończyli lat trzynaście oraz osoby ubezwłasnowolnione częściowo (art. 15), a także osoby, dla których ustanowiono doradcę tymczasowego na czas trwania postępowania o ubezwłasnowolnienie (art. $548 \S 1 \mathrm{kpc}$.). Osoba pełnoletnia może być ubezwłasnowolniona częściowo z powodu choroby psychicznej, niedorozwoju umysłowego albo innego rodzaju zaburzeń psychicznych, w szczególności pijaństwa lub narkomanii, jeżeli stan tej osoby nie uzasadnia ubezwłasnowolnienia całkowitego, lecz potrzebna jest pomoc do prowadzenia jej spraw (art. $16 \S 1 \mathrm{kc}$.). Dla osoby ubezwłasnowolnionej częściowo ustanawia się kuratelę (art. $16 \S 2$ ). Osoba posiadająca ograniczoną zdolność do czynności prawnych może dokonywać czynności prawnych swym działaniem za zgodą przedstawiciela ustawowego. W praktyce orzeczniczej wskazuje się na sytuacje, w których osoba mająca ograniczoną zdolność do czynności prawnych, pomimo iż była matką dziecka, to jako osoba niepełnoletnia i nie posiadająca pełnej zdolności do czynności prawnych (art. $10 \S 1 \mathrm{w}$ zw. z art. $11 \mathrm{kc}$.), nieposiadała zdolności procesowej w postępowaniu administracyjnym zmierzającym do przyznania zasiłku rodzinnego na rzecz własnego dziecka. Uprawnienie to przy- 
sługiwało - zdaniem sądu - babce dziecka, pod której władzą rodzicielską pozostawała niepełnoletnia ${ }^{9}$. W konsekwencji przyjęto, że wnioski małoletniej były nieskuteczne, zaś działania podejmowane przez organy administracyjne na jej wniosek, bez zgody przedstawiciela ustawowego, naruszały prawo.

W doktrynie prawa cywilnego przyjmuje się zasadną sugestię, że przy ustalaniu zdolności procesowej w sprawach administracyjnych należy korzystać również z przepisów kc., które przewidują możliwość samodzielnego działania ograniczonego w zdolności do czynności prawnych (art. 20-22 kc.) ${ }^{10}$. Chodzi tu o sytuacje, gdy osoba ograniczona w zdolności do czynności prawnych może bez zgody przedstawiciela ustawowego dokonywać czynności prawnych innych niż wymienione $\mathrm{w}$ art. $17 \mathrm{kc}$., tj. zawierać umowy należące do umów powszechnie zawieranych w drobnych bieżących sprawach życia codziennego (art. $20 \mathrm{kc}$.), rozporządzać swoim zarobkiem (art. 21 kc.), czy w przypadku określonym w art. 22 kc., zgodnie z którym, jeżeli przedstawiciel ustawowy osoby ograniczonej w zdolności do czynności prawnych oddał jej określone przedmioty majątkowe do swobodnego użytku, osoba ta uzyskuje pełną zdolność w zakresie czynności prawnych, które tych przedmiotów dotyczą. Wyjątek stanowią czynności prawne, do których dokonania nie wystarcza według ustawy zgoda przedstawiciela ustawowego.

W administracyjnym prawie materialnym sporadycznie występują regulacje które przewidują samodzielne działanie osób nieposiadających pełnej zdolności do czynności prawnych, gdyż zasadą jest, że takie osoby działają przez swoich przedstawicieli ustawowych (art. $30 \S 2$ k.p.a.). Przykładem czynności, którą może podjąć nieletni (który ukończył 14 lat) samodzielnie, bez konieczności uzyskania zgody przedstawiciela, jest przystapienie do egzaminu ze znajomości ochrony i połowu ryb, zaś po jego zdaniu, uzyskanie karty wędkarskiej. Ani bowiem z ustawy z dnia 18 kwietnia 1985 r. o rybactwie śródlądowym (Dz.U. Nr 21, poz. 91 z późn. zm.), ani z przepisów wykonawczych nie wynika obowiązek uzyskania zgody przedstawiciela ustawowego na udział $\mathrm{w}$ tym egzaminie. Inaczej kwestię tę uregulowano w przepisach dotyczących egzaminowania osób ubiegających się o uprawnienia do kierowania pojazdami. Z treści $\S 6$ ust. 3 odpowiedniego ${ }^{11}$ rozporządzenia wynika, że szkolenie podstawowe lub dodatkowe może rozpocząć osoba, która posiada pisemną zgodę rodziców lub opiekunów, jeżeli nie ukończyła 18 lat.

Tak więc w przedziale wiekowym 13-18 lat czynny udział osoby fizycznej w postępowaniu administracyjnym w charakterze strony będzie - dla swej ważno-

9 Por. wyrok WSA w Szczecinie z dnia 22 czerwca 2006 r., II SA/Sz 309/06 (Centralna Baza Orzeczeń Administracyjnych, http://orzeczenia.nsa.gov.pl/doc/190A0EA7C5)

10 M. Pazdan, (w:) System Prawa Prywatnego. Prawo cywilne - część ogólna, pod red. M. Safjana, Warszawa 2007, s. 930

11 Rozporządzenie Ministra Infrastruktury z dnia 27 października 2005 r. w sprawie szkolenia, egzaminowania i uzyskiwania uprawnień przez kierujących pojazdami, instruktorów i egzaminatorów, Dz.U. Nr 217, poz. 1834 z późn. zm. 
ści - zasadniczo wymagał zgody jej przedstawiciela ustawowego, chyba że będą to czynności przewidujące możliwość samodzielnego działania ograniczonego w zdolności do czynności prawnych.

\section{Pełnomocnik i jego wiek a skuteczność podejmowanych przez niego czynności}

Strona, będąca osobą fizyczną mająca pełną zdolność do czynności prawnych (czyli ma ukończone lat 18 i nie jest ubezwłasnowolniona), może samodzielnie ustanowić w sprawie pełnomocnika, zaś jeżeli nie ma pełnej zdolności do czynności prawnych, to pełnomocnika może ustanowić wyłącznie przedstawiciel ustawowy strony.

Co ciekawe, z treści art. $33 \S 1$ k.p.a. wynika jednoznacznie, że pełnomocnikiem strony może być wyłącznie osoba fizyczna ${ }^{12}$, w odróżnieniu do procesu cywilnego, gdzie taką funkcję pełnić może również osoba prawna ${ }^{13}$.

W orzecznictwie sądowym wskazuje się, że skierowanie przez organ administracji publicznej decyzji do osoby prawnej (konkretnie - do spółki z o.o.) jako pełnomocnika strony jest równoznaczne ze skierowaniem decyzji do osoby niebędącej stroną w sprawie i powoduje, że decyzja taka jest dotknięta wadą nieważności w rozumieniu art. $156 \S 1$ pkt 4 k.p.a. ${ }^{14} \mathrm{~W}$ literaturze podnosi się wątpliwość, czy ograniczenie kręgu pełnomocników stron do osób fizycznych odpowiada potrzebom i warunkom obrotu prawnego oraz interesom stron postępowania ${ }^{15}$.

Pełnomocnikiem strony może być osoba fizyczna posiadająca zdolność do czynności prawnych. Wskazuje na to ustawodawca w art. $33 \S 1$ k.p.a., gdzie nie przewidziano warunku, aby pełnomocnikiem strony mogła być osoba fizyczna posiadająca pełną zdolność do czynności prawnych. W literaturze wyprowadza się więc z powyższego wniosek, że wystarczy tu ograniczona zdolność do czynności prawnych ${ }^{16}$.

Podobnie sytuacja kształtuje się w postępowaniu podatkowym, tzn. wyłącznie osoba fizyczna może być pełnomocnikiem w postępowaniu przed organami podatkowymi (art. 137 § 1 O.p.).

13 Uchwała składu siedmiu sędziów SN z dnia 23 września 1963 r., III Co 42/63 (OSNC 1965, nr 2, poz. 22).

14 Por. wyrok Wojewódzkiego Sądu Administracyjnego w Warszawie z dnia 21 czerwca 2006 r., sygn. akt I SA/Wa 534/06 (LEX nr 219233) oraz wyrok NSA z 21 marca 2002 r., V SA 2019/01 (Lex nr 109322), w którym stwierdzono, że: „Zrzeszenie Właścicieli Nieruchomości nie mogło być w sprawie administracyjnej o wymeldowanie pełnomocnikiem procesowym właścicieli już choćby z tego względu, że w myśl art. $33 \S 1$ k.p.a. pełnomocnikiem procesowym strony w postępowaniu administracyjnym może być jedynie osoba fizyczna", a także niepublikowany wyrok NSA z dnia 8 marca 2001 r., VI SA 41/99, gdzie przyjęto, że: „Zgodnie z art. 33 § 1 kodeksu postępowania administracyjnego, pełnomocnikiem strony może być osoba fizyczna posiadająca zdolność do czynności prawnych, a więc zarząd stowarzyszenia nie może pełnić funkcji pełnomocnika".

15 Por. A. Wróbel, Komentarz do art. 33 k.p.a., (w:) M. Jaśkowska, A. Wróbel, Kodeks postępowania administracyjnego. Komentarz, wyd. III, Warszawa 2009.

16 Por. J. Borkowski, (w:) B. Adamiak, J. Borkowski, Kodeks postępowania administracyjnego. Komentarz, Warszawa 2009 , s. 213. Twierdzenie powyższe wydaje się być jednak uzasadnione treścią art. 100 kc., zgodnie z któ- 
W sposób bardziej precyzyjny w powyższej kwestii wypowiadał się E. Iserzon, który twierdził, że osoba mająca ograniczoną zdolność do czynności prawnych może być pełnomocnikiem, ale jedynie w takim zakresie, w jakim nie jest ograniczona w zdolności do czynności prawnych ${ }^{17}$.

Nie ma więc podstaw do zupełnego wykluczenia czynności pełnomocnika ograniczonego w zdolności do czynności prawnych, ale nie wydaje się zasadne przyjmowanie jego udziału w postępowaniu jako reguły. Pełnomocnik osoby ograniczonej w zdolności do czynności prawnych mógłby, reprezentując stronę w procesie, dokonywać czynności procesowych jedynie w takim zakresie, w jakim nie stanowią one zaciagnnięcia zobowiązania lub rozporządzenia prawem strony (art. 30 k.p.a. w związku z art. 17 i $18 \mathrm{kc}$.).

W mojej ocenie, do rozważań dotyczących udziału pełnomocnika w czynnościach postępowania administracyjnego należałoby odpowiednio stosować nie tyle ogólne przepisy kc. dotyczące pełnomocnictwa, co regulacje odnoszące się do prokury, jako pełnomocnictwa szczególnego. Zgodnie z treścią art. $109^{1}-109^{2} \mathrm{kc}$. prokurentem może być jedynie osoba fizyczna mająca pełną zdolność do czynności prawnych. Takie założenie pozwalałoby na sprawne przeprowadzenie postępowania, bez konieczności ewentualnego potwierdzania czynności pełnomocnika przez stronę bądź też przez przedstawiciela ustawowego w przypadku pełnomocnika nie ograniczonego w zdolności do czynności prawnych. Trzeba też zdawać sobie sprawę z prawnych konsekwencji ustanowienia pełnomocnika w postępowaniu administracyjnym, np. w zakresie doręczania pism procesowych oraz obowiązku zapewnienia czynnego udziału w prowadzonym postępowaniu. Tak więc - w mojej ocenie - należałoby przyjać, że w postępowaniu administracyjnym pełnomocnikiem może zostać jedynie osoba fizyczna, mająca pełną zdolność do czynności prawnych, czyli pełnoletnia. W stosunku do osób ograniczonych w zdolności do czynności prawnych możliwy i skuteczny jest ich udział - jak się wydaje - jedynie w charakterze posłańców.

rym „okoliczność, że pełnomocnik jest ograniczony w zdolności do czynności prawnych, nie ma wpływu na ważność czynności dokonanej przez niego w imieniu mocodawcy”. Zdaniem E. Strzebińczyka, (w:) Kodeks cywilny. Komentarz pod red. E. Gniewka, Warszawa 2008, s. 247, powyższy przepis ma zastosowanie niezależnie od zakresu zdolności do czynności prawnych, jaką posiadała osoba umocowana w momencie udzielania jej pełnomocnictwa, z uwagi na jednostronny charakter pełnomocnictwa, które ze swej istoty nie wymaga przyjęcia go przez pełnomocnika. 17 E. Iserzon, (w:) E. Iserzon, J. Starościak, Kodeks postępowania administracyjnego. Komentarz (teksty, wzory
i formularze), wyd. 4 zm. i uzup., Warszawa 1970, s. 62. 


\section{Znaczenie wieku świadka dla wartości dowodowej jego zeznań}

Przez świadka rozumie się osobę fizyczną wezwaną przez sąd (lub organ administracyjny) z inicjatywy strony lub z urzędu, w celu złożenia zeznań (udzielenia informacji) o okolicznościach faktycznych przez siebie spostrzeżonych lub też o okolicznościach, o których wie od innych osób (tzw. świadek ze słyszenia) ${ }^{18}$. Istotną cechą świadka powinno być to, że postępowanie nie dotyczy jego praw i obowiązków oraz to, że był on w stanie lub miał możliwość spostrzec okoliczności mające znaczenie dla sprawy. Z powyższych powodów świadek wezwany przez organ obowiązany jest złożyć zeznanie oraz zeznawać w zgodzie z prawdą.

W postępowaniu administracyjnym, w charakterze świadka, występować może osoba fizyczna wezwana przez organ do złożenia zeznań, niezależnie od jej stanu wieku. Ustawodawca wprowadził ograniczenia innego rodzaju w korzystaniu z tego źródła dowodowego. Ograniczenia te mogą wypływać z dwóch rodzajów przyczyn: faktycznych i prawnych ${ }^{19}$, przy czym te pierwsze mogą wiązać się - w pewnym oczywiście sensie - z wiekiem świadka. I tak, z przyczyn faktycznych świadkami nie mogą być „osoby niezdolne do spostrzegania lub komunikowania swych spostrzeżeń" (art. 82 pkt 1 k.p.a.).

Niezdolność spostrzeganiapolegananiemożnościuświadomienia sobieprzedmiotu (zjawiska) spostrzeganego, braku kontroli reakcji narządu zmysłowego na bodziec zewnętrzny ${ }^{20}$. Jak podkreśla W. Siedlecki, ustawodawca ,nie usuwa od zeznań dzieci, w szczególności nie stawia żadnej granicy wieku dla zdolności zeznawania dziecka $w$ charakterze świadka, gdyż zależy to od indywidualnego rozwoju umystowego"21. Tak więc ocena, czy małoletni ma zdolność do postrzegania lub komunikowania swoich spostrzeżeń, należy każdorazowo do organu prowadzącego postępowanie. Oczywiście, należy każdy przypadek analizować oddzielnie, biorąc pod uwagę całokształt okoliczności, w jakich zeznania mają być składane.

Niezdolność komunikowania swoich spostrzeżeń polega na braku umiejętności przekazywania informacji za pośrednictwem symboli, którymi są słowa oraz sygnały pozawerbalne (np. wyraz twarzy, pozawerbalne dźwięki mowy, ruchy ciała, gesty) ${ }^{22}$. W doktrynie przyjmuje się, że osoba, która „Z racji pewnych ułomności może komunikować swoje spostrzeżenia w sposób zrozumiały dla niektórych osób, np. za pomocą alfabetu głuchoniemych, może być powołana w charakterze świadka, jeżeli

18 T. Wiśniewski, Przebieg procesu cywilnego, Warszawa 2009, s. 217.

19 S. Kalinowski, Dowód z opinii instytutu, zakładu i urzędu w postępowaniu sądowym i administracyjnym, Warszawa 1967, s. 186.

20 Por. W. Siedlecki, Postępowanie cywilne w zarysie, Warszawa 1972, s. 327.

21 Ibidem, s. 328, podobnie E. Iserzon, Komentarz IV, s. 172.

22 Wielka Internetowa Encyklopedia Multimedialna, http://wiem.onet.pl/wiem/000c42.html 
zapewni się jednocześnie udział biegłego w postępowaniu”23. Przyjęcie powyższego rozwiązania uwarunkowane jest jednak wystapieniem u świadka łącznie obu elementów, tj. musi on postrzegać fakty oraz ma możliwość ich komunikowania.

$\mathrm{Na}$ gruncie k.p.a. nie został uregulowany sposób przeprowadzania czynności dowodowej przesłuchania. Ustawodawca $\mathrm{w}$ tym zakresie pozostawił organom względną swobodę. Zobowiązał jednak organ, aby przed odebraniem zeznań uprzedził świadka o prawie odmowy zeznań i odpowiedzi na pytania oraz o odpowiedzialności za złożenie fałszywych zeznań. Nie ulega jednak wątpliwości, iż przesłuchanie świadka musi odbywać się w warunkach stwarzających mu możliwość swobodnej wypowiedzi. Do stworzenia tych warunków obowiązany jest organ przeprowadzający czynność dowodową przesłuchania. Za niedopuszczalne należy uznać np. przyjmowanie zeznań przez osobę nietrzeźwą czy też będącą pod wpływem lekarstw ograniczających świadomość ${ }^{24}$.

Natomiast w przypadku, gdy istnieje wątpliwość co do stanu psychicznego świadka, stanu jego rozwoju umysłowego, zdolności postrzegania lub odtwarzania spostrzeżeń, należałoby zarządzić przesłuchanie świadka z udziałem biegłego (lekarza lub psychologa), na wzór regulacji przewidzianej w art. $192 \S 2 \mathrm{kpk}$. Wydaje się, że takie postępowanie byłoby uzasadnione ze względu na trudności wiążące się z dokonaniem obiektywnej w tym zakresie oceny, która przekraczać może wiedzę i umiejętności pracowników organów administracji publicznej.

Podsumowując, należy uznać, że ustawodawca wprost nie uzależnił możliwości powołania osoby fizycznej w charakterze świadka od osiagnięcia przez nią konkretnego wieku. Także wartość dowodowa zeznań nie powinna być kontestowana wyłącznie z powodu wieku świadka, niezależnie, czy chodzi o jego niepełnoletniość, czy też z uwagi na wiek podeszły. Świadek, aby móc stanowić rzetelne osobowe źródło dowodowe, musi mieć możliwość postrzegania faktów oraz ich komunikowania. Odrębną kwestią jest oczywiście ocena wiarygodności zeznań, która powinna być dokonywana w całokształcie materiału dowodowego. Nie jest więc zasadne dokonywanie oceny zeznań świadków ,ze szczególną ostrożnością, biorąc pod uwagę podeszły wiek świadków, jak również to, że przesłuchiwani byli na okoliczności sprzed 60-ciu lat, gdy byli dziećmi"25. Analiza zeznań powinna być dokonywana raczej pod kątem tego, czy nie są one sprzeczne z rzeczywistym stanem wynikającym $\mathrm{z}$ całokształtu zgromadzonego materiału dowodowego.

23 J. Borkowski, (w:) B. Adamiak, J. Borkowski, Kodeks postępowania administracyjnego. Komentarz, Warszawa 2009, s. 170.

Por. S. Waltoś, Proces karny. Zarys systemu, Warszawa 1996, s. 339.

25 Tak w uchylonym przez NSA wyroku WSA w Warszawie z dnia 6 listopada 2006, IV SA/Wa 1457/06 (Centralna Baza Orzeczeń Sądów Administracyjnych, http://orzeczenia.nsa.gov.pl/doc/1ACD85BB50) 


\section{Relacje między wiekiem biegłego a wiadomościami specjalnymi}

Biegłym jest osoba fizyczna, nie posiadająca interesu prawnego ani faktycznego w sprawie, powołana $z$ urzędu lub na wniosek strony do oceny okoliczności faktycznych przez organ prowadzący postępowanie, z uwagi na posiadane przez nią wiadomości specjalne. W kpa. nie wprowadzono wymagań formalnych stawianych biegłemu, nie definiując jednocześnie pojęcia „wiadomości specjalnych”.

Oznacza to, że biegłym w ogólnym postępowaniu administracyjnym może być zarówno osoba wpisana na przewidzianą przepisami szczególnymi listę biegłych (rzeczoznawców), jak i osoba spoza tej listy, o ile posiada wiedzę fachową w danej dziedzinie ${ }^{26}$. Ustawodawca nie wprowadza jednak jakichkolwiek kryteriów, w oparciu o które organ miałby oceniać wiadomości specjalne biegłego.

W orzecznictwie Sądu Najwyższego ukształtował się pogląd, iż do wiadomości specjalnych należy zaliczyć wszelkie te wiadomości oraz umiejętności, które wykraczają poza przeciętne i praktyczne ${ }^{27}$. Do wiadomości specjalnych nie należą więc „wiadomości dostępne dla dorosłego człowieka o odpowiednim doświadczeniu życiowym, wykształceniu i zasobie wiedzy ogólnej"28. Przyjmuje się też powszechnie pogląd, iż organ procesowy nie może zastępować biegłego i rezygnować z jego opinii, jeżeli ustalenie danej okoliczności wymaga wiedzy specjalistycznej ${ }^{29}$, zaś orzekający w sprawie nie może odrzucić wszystkich opinii specjalistycznych i przyjąć w sprawie własnego, odmiennego stanowiska ${ }^{30}$.

$\mathrm{Na}$ gruncie regulacji prawnych dotyczących postępowań sądowych mamy do czynienia z biegłymi sądowymi, wpisanymi na listę prowadzoną przez prezesa sądu okręgowego ${ }^{31}$, których ustanawia się dla poszczególnych gałęzi nauki, techniki, sztuki, rzemiosła, a także innych umiejętności. Pojęcie wiadomości specjalnych rozumie się tu niezwykle szeroko, bowiem oznaczają one nie tylko wiedzę naukową, ale także umiejętności praktyczne, oparte na doświadczeniu i obserwacji najróżniejszych dziedzin.

Jednakże, o ile w procesie cywilnym może uczestniczyć wyłącznie ten biegły, który - obok spełnienia innych warunków - ukończył 25 lat ${ }^{32}$, o tyle w postępo-

\footnotetext{
26 Por. E. Iserzon (w:) Komentarz IV, 1970, s. 176: „Biegłym może być osoba posiadająca specjalne wykształcenie, jak i nie mający takiego wykształcenia praktyk, który faktycznie ma potrzebne organowi wiadomości”. Por. wyrok SN z 23 listopada 1982 r., II KR 186/82 (OSNPG 1983, nr 5, poz. 59).

32 Zgodnie z $\S 12$ ust. 1 pkt 2 cyt. rozporządzenia, biegłym może być ustanowiona osoba, która ukończyła m.in. 25 lat życia.
} 
waniu administracyjnym ta granica wiekowa nie została precyzyjnie ustanowiona. Oczywistym jest, że osiagnięcie wysokiego poziomu wiedzy specjalistycznej czy to naukowej, czy też opartej o zdobyte doświadczenie, wiązać się musi nieuchronnie z upływem określonego czasu, a co za tym idzie - osiągnięciem pewnego wieku przez takiego specjalistę. Nie można jednak wykluczyć, że w określonej sprawie administracyjnej może okazać się, że w obszarze danej dziedziny wiedzy jedynym (bądź najlepszym) specjalistą będzie osoba niepełnoletnia. Sam fakt osiagnięcia (bądź nie) określonego wieku nie może jednak mieć znaczenia decydującego o wyborze specjalisty.

\section{Podsumowanie}

Ogólne postępowanie administracyjne nie zostało przez ustawodawcę sformalizowane w taki sposób, aby nadać kwestii precyzyjnego określenia wieku uczestników postępowania znaczenie decydujące dla możliwości ich udziału w postępowaniu administracyjnym. Osiagnięcie określonego wieku przez stronę postępowania nie ma dla jej bytu prawnego bezpośredniego znaczenia procesowego. Jest to bowiem kwestia materialnoprawna, regulowana przepisami szczególnymi.

Kryterium wieku uczestników postępowania będzie jednak miało istotne znaczenie przy ustalaniu ich zdolności procesowej. Skuteczność podejmowania czynności procesowych przez stronę, a także przez pełnomocnika strony została na gruncie k.p.a. uwarunkowana koniecznością osiagnięcia określonego poziomu zdolności do czynności prawnych, który to osoba fizyczna nabywa właśnie poprzez spełnienie kryterium wieku (odpowiednio 18 lat dla pełnej zdolności do czynności prawnych, zaś 13 lat dla zdolności ograniczonej). Jest to rozwiązanie systemowe, stosowane powszechnie w sferze prawa cywilnego, do którego odsyła k.p.a. i trudno z nim dyskutować (może poza sygnalizowaną kwestią potrzeby przyjęcia warunku posiadania pełnej zdolności do czynności prawnych przez pełnomocnika).

Inaczej jednak kształtuje się sytuacja w przypadku świadków i biegłych, gdzie kwestia wieku uczestnika procesowego nie ma bezpośredniego znaczenia dla sprawy. Owszem, wiek wczesnodziecięcy może mieć i najczęściej ma wpływ na sposób postrzegania i komunikowania spostrzeżeń przez świadka, a tym bardziej na zakres posiadanej wiedzy specjalistycznej. Ale jest to raczej okoliczność stanowiąca przyczynę niespełnienia ustawowego kryterium warunkującego możliwość powołania takiej osoby na świadka. Można więc stwierdzić, że kwestia osiagnięcia konkretnego wieku pośrednio oddziaływa na możliwość powołania określonych osób fizycznych do udziału w postępowaniu administracyjnym w charakterze świadka lub biegłego. 
Dokonując oceny sposobu regulacji związanych z wiekiem świadka i biegłego przyjętej na gruncie k.p.a., należy je ocenić pozytywnie. Wydaje się, że w tym zakresie sztywno określone ramy wiekowe byłyby rozwiązaniem sztucznym i mało elastycznym z punktu widzenia dynamicznego rozwoju społecznego i technicznego.

Użycie przez ustawodawcę klauzuli generalnej w postaci pojęcia „wiadomości specjalne" daje organom możliwość swobodnego wyboru biegłego w oparciu o luz interpretacyjny, pozwalający na branie pod uwagę także kryteriów pozaprawnych, mających często istotne znaczenie praktyczne. 


\title{
THE AGE OF ADMINISTRATIVE PROCEDURE'S PARTIES VERSUS VALIDITY OF THEIR LEGAL ACTIVITIES
}

\author{
SUMMARY
}

The scope of article presented are reflexions on legal limitations concerning the age of natural persons undertaking actions within administrative procedure.

There are four general, basic categories of such participants indicated in the article: party, party's legal representative, witness and expert.

The conclusion goes towards statement, that the criterion of the procedure's participants' age has different importance according to validity of their procedural activities. In the case of a party as well as party's representative, their activities' validity depend on the level of their ability to undertake legal activities which is connected to the age (age of 18 to obtain full ability to undertake legal activities and age of 13 for limited ability).

The situation of witnesses and experts differs. In general their age does not influence the case. But it seems to be obvious that the young age implicates the way of perception and communication, as well as range of specific knowledge. 